\title{
Cancer Treatment by Greco-Arab and Islamic Herbal Medicine
}

\author{
Hilal Zaid ${ }^{1}$, Anwar Rayan $^{1}$, Omar Said ${ }^{1,2}$ and Bashar Saad ${ }^{1,3, *}$ \\ ${ }^{1}$ Qasemi Research Center-Al-Qasemi Academic College, P.O Box 124, Baqa El-Gharbia 30100, Israel \\ ${ }^{2}$ Antaki Center for Herbal Medicine, P.O Box 2205, Kufur kana 16930, Israel \\ ${ }^{3}$ Faculty of Arts and Sciences, Arab American University Jenin, P.O Box 240, Jenin, Palestine
}

\begin{abstract}
Islamic medicine, Arabic medicine, Arab-Islamic medicine, or Greco-Arab and Islamic medicine refers to medicine developed in the Golden Age of the Arab-Islamic civilization, which extended from Spain in the west to Central Asia and India in the east. In temporal terms it covered a period of roughly nine centuries, from the middle of the seventh to the end of the fifteenth century. Medicine was a central part of this medieval civilization. Famous Arab and Muslim physicians, e.g., Rhazes, Avicenna, Al Zahrawi, Ibn al Nafis studied and developed treatments regimes for cancer as well as most known diseases at that time. They described most types of cancers which were known at that time and suggested several therapies. This review is an eye-bird view on the ancient Arab-Greco and Islamic cancer diagnosis, herbal treatment and nowadays herbal treatment research.
\end{abstract}

Keywords: Cancer, medicinal plants, Arab herbal medicine, Avicenna, garlic, black seeds.

\section{INTRODUCTION}

Cancer is a leading cause of death worldwide. Statistics indicated that cancer strikes more than one third of the population and it's the cause of more than $20 \%$ of all deaths [1]. Cancer is a cohort of diseases in which abnormal cells divide without control and are able to invade other tissues (through the blood and lymph systems). More than 100 different types of cancer are known, usually are named by the organ or type of cell in which they start - for example, cancer that begins in the colon is called colon cancer. Cancer is caused due to abnormalities in the DNA of the affected cells leading to an extra mass of tissue called a tumor. Tumors may be benign (not cancer), or malignant (cancer). Among many others, the causes of cancer might be tobacco smoke, infection, chemicals, radiation and unhealthy diet.

Cancer cells are able to grow, invade neighboring tissues and may also affect other organs. Therefore, tumors arise when cells lose their ability to undergo regulated cell growth. If the tumor is diagnosed at an early stage, it can be successfully treated by surgery and radiation. Advanced tumors are treated usually by chemotherapy and although these drugs are effective, they are associated with severe adverse events and drug resistance [2,3]. In the search for new cancer therapeutics with low toxicity and minimal side effects, traditional Islamic medicines might be promising candidates [49].

During the Golden Age of the Arab-Islamic civilization ( $7^{\text {th }}$ to $14^{\text {th }}$ century) many of the famous Arab-Muslim physicians studied cancer and applied various medicines and

*Address correspondence to this author at the Qasemi Research Center- AlQasemi Academic College, P.O Box 124, Baqa El-Gharbia 30100, Israel; Tel: +972-4-9504523/4; Fax: +972-4-9504525;

E-mail: bashar@qsm.ac.il; bashar@aauj.edu surgical methods. For instance, Ibn Sina (980-1037), known in the west as Avicenna, was the most influential of all Islamic philosopher-scientists, suggested "When cancer starts, it may be possible to keep it as it is, so that it will not increase and keep it non-ulcerated. It may happen sometimes that the stating cancer may be cured. But when it is advanced, verily will not". Hence, it is worthwhile looking back in the history to the views of old masters in the GrecoArab medicine. It is appropriate to introduce first the history of the Greco-Arab and Islamic medicine for the reader who is not familiar with it.

The history of the Greco-Arab and Islamic medicine is divided into two phases: Greek-to-Arab phase and ArabMuslim phase. The first phase started in the eighth century (A.C) when the Muslims empire ruled about two-thirds of the world. This magnificent spread allowed them to get and translate Greek scientific and philosophical manuscripts as well as Indian and Persian scripts. Hunayn Ibn-Is'haq (809873), translated a large number of scientific and medical manuscripts in Greek (including philosophical works by Galen, Plato, Aristotle, Euclid and Archimedes) into Arabic during the glory years of the Abbasid Caliphate (756-945) [10].

During the second phase, by 850 , most of the philosophical and scientific works of Aristotle; much of Plato and the Pythagorean School; and the major works of Greek astronomy, mathematics and medicine and the works of Hippocrates and Galen, were all rendered into Arabic. For the next 700 years, Arabic became the most important scientific language of the world and the repository of much of the wisdom and the sciences of antiquity [6,11-13]. During this golden age of the Arab-Islamic civilization, numerous scientific and medical innovations were introduced: The discovering of the immune system, the introduction of microbiological science, 
the Introduction of scientific methods to medicine, including animal tests, clinical trials, and quantification and the separation of medicine from pharmacological science. For instance, the earliest known medical experiment was carried out by Rhazes (865 - 915) (Fig. 1). In his Comprehensive "Book of Medicine", Rhazes described clinical cases of his own experience and provided very useful recordings of various diseases. Avicenna's (Ibn Sina, 980-1037) (Fig. 2) wrote almost 450 treatises on a wide range of subjects, of which around 240 have survived and 40 of them concentrate in medicine. Perhaps "The Canon of Medicine" is the most comprehensive and the best-known amongst them. The Canon of Medicine was a standard medical text in Europe and the Islamic world up until the $18^{\text {th }}$ century. Avicenna and many other Arab and Muslim scientists introduced numerous new ideas, upgraded the knowledge about herbs and their potential medical efficacy and safety [14].

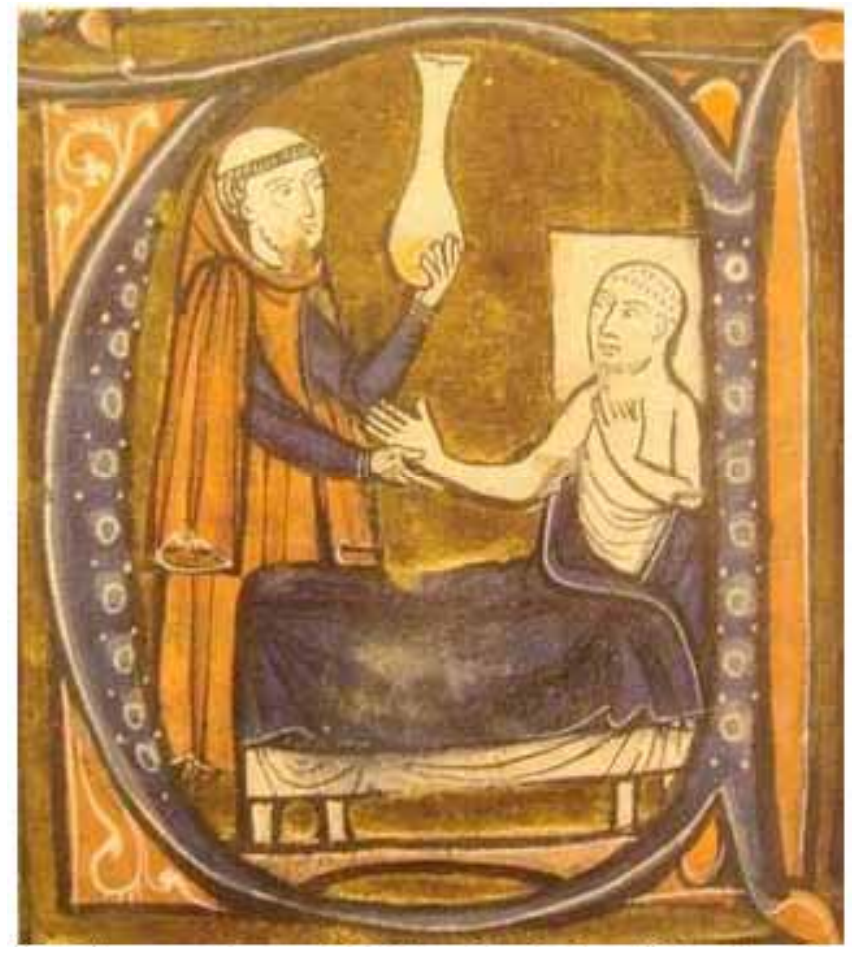

Fig. (1). Al Razi, known as Rhazes (860-930) was born in Rayy (in Persia), where he was well trained in the Greek sciences. He was chief physician at the Baghdad hospital. He developed many chemical apparatuses used up to the beginning of the twentieth century, and classified chemicals and described procedures for their mixing and preparation that were later adopted by the Western world. He was also the first to propose the theory of acquired immunity by recognizing that individuals surviving smallpox never get it again. Other contributions to the field of medicine include several innovations in pharmacy and chemistry.

\section{CANCER DIAGNOSTIC AND TREATMENT BY THE GRECO-ARAB AND ISLAMIC MEDICINE}

The most effective way for illness prevention in Islam is healthy diet. Prophet Mohammad, Peace Be upon Him (PBUH) said "food is the source of illness; however the diet program is the source of health". Avicenna also had discussed the diet effect on cancer progression. In regard of cancer prevention he said that "As to preventing its (cancer) progress, it can be achieved by ... improving the diet and reinforcing the involved organ by the known effective medications ..." It is well known nowadays that several chemicals are carcinogenic $[15,16]$ and that obesity is a cause of various diseases including cancer $[17,18]$.

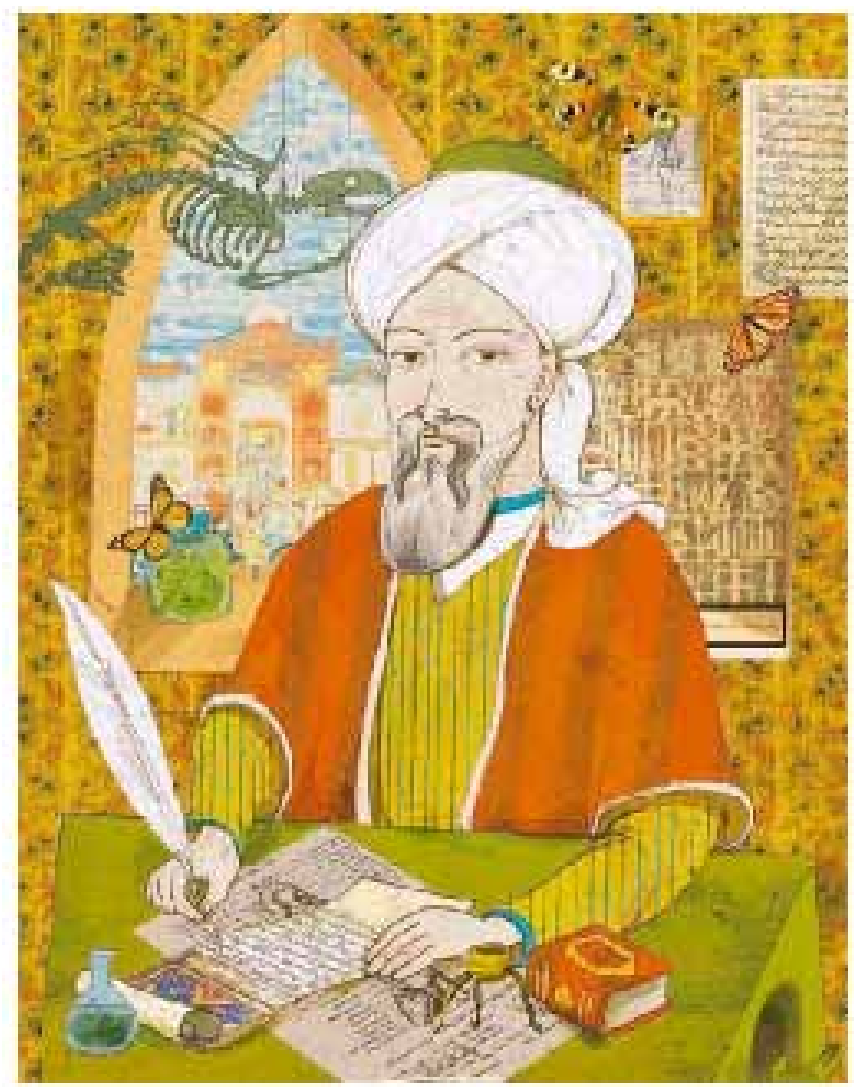

Fig. (2). Abu Ali al-Husayn ibn Abd Allah ibn Sina (980-1037), known in the west as Avicenna, was the most influential of all Islamic philosopher-scientists. He wrote 16 books on medicine, 68 books on philosophy and theology, 11 on astronomy and science, and others. Began his studies in Bukhara under the guidance of several well-known scholars of the time. About 450 treatises were ascribed to Avicenna. The best-known amongst them is his 14volume The Canon of medicine, which was a standard medical text in Western Europe for seven centuries. One of the most important citations of Avicenna concerning psychological and organ diseases: "We have to understand that the best and effective remedy for the treatment of patients should be through the improvement of the power of the human body in order to increase its immune system, which is based on the beauty of the surroundings and letting him listen to the best music and allow his best friends to be with him".

Some of the Greek physicians, especially Galen (129199) were acquainted with tumors. It is believed that Galen was the first to deal with tumors, including cancer, in a systematic way. He adopted Hippocrates' (470-370 BC) basic theory of cancer as an excess of black bile. In the golden Islamic-Arab time, classic Greek texts including those of Galen, were translated into Arabic, and influenced physicians in the Arab-Islamic world. Disease, including cancer, was viewed in terms of the four Greek bodily fluids (Humors): blood, phlegm, yellow bile, and black bile. It is 
worth however to emphasize that Rhazes, Avicenna and Abulcasis had described in more details specific cancer and tumor types and developed novel ways of treatment as shall be discussed herein.

Arab and Muslim physicians identified several cancer types, including eye, nasal, tongue, stomach (gastric), liver, the urinary system, kidney, testis, and breast cancer, as well as spleen and nerve tumor. For instance, kidney's cancer was mentioned clearly, for the first time, by Al Zahrawi (Abulcasis 936 - 1013 AC) who had distinguished between kidney acute inflammation and kidney cancer. Both; Rhazes and Avicenna described cancer as a tumor which is extremely difficult disease to treat.

In his Canon, Avicenna described four ways to treat cancer: (a) total arrest (but it is difficult); (b) preventing its progress; (c) preventing ulceration; (d) treating of ulceration. He empathized that the medications should not be of much strength, since strong medications increase cancer evil. In addition, one should avoid irritant medications and for this, good medications are: pure minerals like washed pure tutty mixed with oils like rose oil and the oil of yellow gillyflower mixed with it [10].

All the earlier Arab and Muslim scholars, including Rhazes, Abulcasis and Avicenna realized that a cure is most likely if the cancer was identified at its earliest stage [10, 19]. The first goal of a treatment strategy should be to halt the cancerous growth. They suggested surgical removal if the tumor was small and accessible, and not close to major organs. For instance, when Avicenna described one of the very early surgical treatments for cancer, in his Canon, he noted: "the excision should be radical and that all diseased tissue should be removed, which included the use of amputation or the removal of veins running in the direction of the tumor ... so that nothing of these will be left". He also recommended the "use of cauterization for the area being treated if necessary". Other citation by Avicenna ".... and it was told by one of the predecessors that a physician had excised a cancerous breast radically then cancer developed in the other breast. My opinion is that the second breast might have been on its way to cancerization (a dormant cancer) which fits this case and it is possible to be a spread of the material (cancerous from the first breast) and this is more evident (opinion)...". Avicenna also attempted the earliest known treatments for cancer. One method he discovered was the "Hindiba", (chicorium intybus) an herbal compound drug which Ibn al-Baitar later identified as having anticancer properties and which could also treat other tumors and neoplastic disorders [6, 11-13, 20-22].

\section{PREVENTION AND TREATMENT OF CANCER IN THE GRECO-ARAB AND ISLAMIC HERBAL MEDICINE}

Herbal medicine has been used worldwide as traditional medicines for thousands of years to treat various forms of diseases including cancer. Chemoprevention, a novel approach for controlling cancer, involves the use of specific natural products or synthetic chemical agents to reverse, suppress or prevent pre-malignancy before the development of invasive cancer. Several natural products, such as, grains, nuts, fruits, vegetables and medicinal plants confer protec- tive effects against wide range of cancers. Since diet has an important role in the body health, dietary chemoprevention received attention in the Arab-Islamic treatment of diseases including cancer. The holy Quran mentions many plants as well as animal products among the foods Muslims can enjoy and benefit from their nutritional and health values. Among some of the foods mentioned in the holy Quran and Hadith by the Prophet (PBUH) are grapes, citrus, melon, squash, Figs dates, honey, olive oil, and black seeds. The Prophet (PBUH) mentioned Figs and then stated, "If I had to mention a fruit that descended from paradise I would say this is it because the paradisiacal fruits do not have pits...eat from these fruits for they prevent hemorrhoids, prevent piles and help gout." Figs are a top source of fiber, as well as potassium and vitamin B6. Fiber results in bulkier stools, which lessen the incidence of constipation, hemorrhoids and colon cancer. Melon was among one of the fruits most often eaten by the Prophet. In fact, melon is one of the best recommendations for health the Prophet has given us. Melon is one of the few fruits and vegetables rich in vitamin C, BetaCarotene, and potassium. He recommended the use of olive oil, by a statement "Eat olive oil and massage it over your bodies since it is a holy (Mubarak) tree". Black seeds were regarded as a medicine for that cures all types of diseases. The Prophet once stated, "The black seed can heal every disease, except death". Dates are mentioned in twenty places in the Quran. Prophet (PBUH) is reported to have said: "if anyone of you is fasting, let him break his fast with dates. In case he does not have them, then with water. Verily water is a purifier".

As stated above, Avicenna had described four approaches to treat cancer, he had also mentioned that "it (cancer) can be reached by controlling the material (atrabile), improving the diet and reinforcing the involved organ by the known effective medicines, and by using mineral smears like those containing millstone dust and whet-stone dust and from smears taken from a mixture between the stone pounder for aromatics and black head stone moisturized with rose oil and coriander water poured on pounder. And also a dressing with well pounded verjuice is good and useful".

As to those (medications) which are needed to prevent ulceration they are the smears that prevent its (cancer) progress provided they will not be irritant; all of them are useful, especially if mixed with the mixture mentioned from lead stone and stone pounder of aromatics. And if added to the total sealing clay or Arminian bole or underground oil (mineral oil?) or houseleek water, ceruse and letturce juice, or the mucilage of fleawart or ceruse of lead (all) constitute a good preparation. And of great benefit is the dressing with raw (soft) fluvial cancer (crab) especially with scoria (zinc oxide)

As to the treatment of the ulceration what is good for it is a continuous linen soak, soaked in fox-grape water (hound's berry?)' when the soak dries up it is moistened again with the same kind of water [10].

And to take the kernels of common wheat, Frankincense and ceruse (white lead) one dirham (drachm weight) and from Arminian bole, sealing clay and washed aloes two dirhams of each put together and pounded and is to use it on 
the wet (part of the ulcer) as sprinkles and on the dry (part of the ulcer) as an ointment using rose oil [10].

And what may be useful is the ash of the cancer (crab) with salve (cerate?) with rose grease (oil). And better than that is to mix equal amounts of scoria (zinc oxide). And it may be beneficial to use the tutty prescription or the tutty washed with pursulane juice (water) or the mucilage of flea-wart [10].

Due to place limitations we will focus on six widely used herbal products, namely, garlic, onion, black seeds, pomegranate, Bread wheat and olive leaf and fruits. Other commonly used medicinal plants and wild edible plants are described in Table $\mathbf{1}$.

\section{GARLIC AND ONION (ALLIUM SATIVUM L. AND ALLIUM CEPA L)}

Onion (Allium cepa) and garlic (Allium sativa) are closely-related vegetables that belong to the Allium class of bulb-shaped plants, which also includes onions, chives, leeks, and scallions. Garlic is used for flavoring in cooking and is unique because of its high sulfur content. In addition to sulfur, garlic also contains arginine, oligosaccharides, flavonoids and selenium, all of which may be beneficial to health [23]. In fact onion and garlic are used in the treatment and prevention of a number of diseases, including cancer, coronary heart disease, obesity, hypercholesterolemia, diabetes type 2 and hypertension. Scientific research on garlic started in the 19th century with the work of Louis Pasteur who in 1858 first noted antibacterial properties of garlic [24].

The association between consumption of Allium vegetables and risk for cancer has been first assessed in several epidemiologic studies, mainly case-control, to show the protective effect of garlic and onion against cancer. For instance, death (attributed to stomach cancer) was 10 fold higher in a high risk area where the garlic consumption is less than $1 \mathrm{~g} /$ day compare to the low risk area ( $20 \mathrm{~g} /$ day) [25, 26]. Similar studies in Netherlands had also attributed the low risk for colorectal, breast, and lung cancers to onion and garlic consumption [27].

Findings from a study on the association between garlic consumption and colon cancer risk, shows clearly that women who consumed the highest amounts of garlic had a 50 percent lower risk of cancer of the distal colon compared with women who had the lowest level of garlic consumption [28]. Garlic and onion consumption was also associated with reduced risk of esophageal and stomach cancers, with greater risk reductions seen for higher levels of consumption [29]. Similarly, in another study, the consumption of allium vegetables, especially garlic and onions, was linked to a reduced risk of stomach cancer [30], an approximately 30-50 percent reduction in prostate cancer risk [31, 32], pancreatic cancer [33] and other distinct cancer types [34]. Moreover, breast cancer risk was reduced in women consuming greater amounts of fiber garlic, and onions [35]. The amount of garlic consumed on the above studies varied from 2 up to $20 \mathrm{~g}$ daily. It is worthy to note that although garlic has been used safely in cooking, excessive consumption can cause some side effects, in addition to strong breath and body odors [36]. The World Health Organization (WHO) guidelines for general health promotion for adults is a daily dose of 2 to $5 \mathrm{~g}$ of fresh garlic (approximately one clove), 0.4 to $1.2 \mathrm{~g}$ of dried garlic powder, 2 to $5 \mathrm{mg}$ of garlic oil, 300 to $1,000 \mathrm{mg}$ of garlic extract, or other formulations that are equal to 2 to 5 $\mathrm{mg}$ of allicin (the active compound in garlic).

Onion and garlic organosulfur compounds protective effect against carcinogenesis was also evaluated in animal models. When administrated to mice 2-4 days prior to carcinogen challenge. Those compounds inhibited pulmonary adenoma formation. Moreover, garlic allylic compounds induced increased glutathione S-transferase (GST) activity in the mice organs especially the forestomach [37]. Organosulfur compounds modulate the activity of several metabolizing enzymes that activate (cytochrome P450s) or detoxify (glutathione S-transferases) carcinogens and thus inhibit the formation of DNA adducts in several target tissues.

Garlic and onion extracts and active compounds efficacy on cancer prevention/treatment was evaluated in-vitro. Tumor cell (including human, lung, skin and colon tumor cell lines, human neuroblastoma cells, human and murine melanoma cells, and human prostatic carcinoma cells [3841]) proliferation inhibition by organosulfur compounds in vitro has supported the in vivo and the case-control studies. Intravenous administration of the garlic active compound (diallyl trisulfide) significantly retarded the growth of orthotopically transplanted hepatoma in BALB/c nude mice [42].

The protective effect of Allium vegetables against tumor proliferation and angiogenesis is attributed mainly to its organosulfur compounds especially allicin and diallyl disulfide [43]. Those active compounds are able to block the formation of cancer-causing substances [44], halt the activation of cancer-causing substances [45, 46], enhance DNA repair [47], reduce cell proliferation, or induce apoptosis programmed cell death (Fig. 3 and [43, 48-51]).

\section{BLACK SEEDS (NIGELLA SATIVA)}

Nigella sativa is one the most revered medicinal seeds in history. In civilizations around the world, herbal spice Nigella Sativa referred to as Habbat-el-barakah (literally seeds of blessing in Arabic), Kalonji (Hindi), Kezah (Hebrew), Sijah Daneh (Persian) and in English called Black Caraway. The famous Greek physician Dioscorides (40-90 AC) used black cumin seeds to treat headaches and toothaches. Nigella sativa seeds and oil extracts has been used widely for centuries to treat interruptions in the respiratory system, stomach, kidney and liver function, circulatory, the immune system as well as cancer. In Islam, it is regarded as one of the greatest forms of healing medicine available [52]. The prophet Mohammad (PBUH) stated, "The black seed can heal every disease, except death". Avicenna refers to black seed in his Canon of Medicine, as the seed that stimulates the body's energy and helps recovery from fatigue and dispiritedness. In the Unani Tibb system of medicine, seeds are regarded as a valuable remedy for a number of diseases. The seed's oil has been used to treat skin conditions such as eczema and boils and to treat cold symptoms.

The modern research confers that Nigella sativa seeds ethanol extract possess antitumor activity in mice tumor primary cells [53]. Nigella sativa seeds extracts contains amino acids, proteins, carbohydrates, alkaloids, saponins, fixed and volatile oils, and many others. Among the volatile 
Table 1. Commonly used Medicinal Plants in Cancer Treatment and Prevention. Based on an Old Literature and Recent Ethnopharmacological Survey, We have Identified the Most Used Plants in Arab-Islamic Medicine for the Treatment of Cancer

\begin{tabular}{|c|c|c|}
\hline Plant Species & Part Used & Additional Uses \\
\hline Allium cepa. & Bulb & Diabetes, liver disease, external infection \\
\hline Allium sativum & Fruit & Treat high cholestrol, parasites, respiratory problems, \\
\hline Anetheum graveolens & Seeds & Intestine gas, digestive system, eye inflammations. \\
\hline Artemisia absinthium & Seeds & Intestinal parasite \\
\hline Arum palaestinum & Leaf & Urinary system \\
\hline Astoma seselifolium & Bulb & General tonic, aphrodisiac increasing appetite \\
\hline Brassica oleracea & Whole plant & Respiratory system, asthma, joint inflammation, bacterial infection \\
\hline Ceterach officinarum & Seeds & Constipation, internal bleeding. \\
\hline Chrysthanemum coronarium & Flower & Fever \\
\hline Crataegus azarolus & Fruit and flower & Cardiovascular diseases, sexual weakness, diabetes \\
\hline Crocus sativus & Fiber & Constipation, liver diseases, eye inflammations. \\
\hline Cuminum cyminum & Seeds & Coughing, urinary infections, kidney stones, liver, digestion problems and intestine gas \\
\hline Curcuma longa & Root & Alzheimer, psoriases, inflamation \\
\hline Cuscuta campestris & Stem & Urinary system problems \\
\hline Eryngium creticum & Leaf and seeds & Ulcer, gallbladder and kidney stones \\
\hline Ficus sycomorus & Fiber and stem & Psoriasis, warts \\
\hline Ficus carica & Fruit and liquid & Laxative, inflammation, wounds, warts \\
\hline Glycyrrhiza glabra & Root & Ulcer, cough ping, liver Constipation. \\
\hline Juglans regia & Leaf and bark & Diabetes, asthma, sexual weakness, tooth whitening, fungi \\
\hline Lens culinaris & Seeds & Inflammation in mouth, skin. \\
\hline Lilium candidum & Flowering parts & Headache. \\
\hline Matricaria aurea & Flowers & Stomach, intestine pain, coughing, Anti inflammatory, Urinary system \\
\hline Narcissus tazetta & Bulb and flowers & Lung inflammation, coldness \\
\hline Nigella sativa & Seeds & Diarrhea, fever, intestine parasites, vomiting, general tonic, skin diseases \\
\hline Opium (papaver somniferum) & Fruits & Insomnia, pain, diarrhea \\
\hline Peganum harmala & Leaf & Inflammation, depression, analgesic \\
\hline Pistacia Lentisaues & Seeds and leafs & Sexual weakness jaundice, and respiratory, problems \\
\hline Punica granatum & Bark & Diarrhea, dysentery, ulcer, wounds \\
\hline Quercus calliprinos & Bark, stem and fruits & Fever, ulcer and high blood pressure. \\
\hline Quercus calliprinos & Fruit and bark decoction & Bed wetting, ulcer, diabetes, skin diseases \\
\hline Quercus ithaburensis & Stem, bark and fruit & Fever, bed wetting, high blood pressure, ulcer \\
\hline Sinapis arvensis & Seed and leaf & General tonic, back pain, rheumatism. \\
\hline Triticum aestivum. & Shoot & Anaemia, skin disease (seed decoction) \\
\hline Urtica pilulifera & Foliage and root & Stomach, intestine pain and inflammation, liver disease, bed wetting (seed) \\
\hline Vicia faba & Seeds & Skin diseases, whitening \\
\hline Vinca rosa & Leaf & Diabetes \\
\hline Viscum cruciatum & Seeds, fruit, Foliage & Constipation, rheumatism, back ache. \\
\hline Zea mays & Kernel and fibre & Urinary system and stones in kidney, blood pressure, joint inflammation and weight loss \\
\hline
\end{tabular}




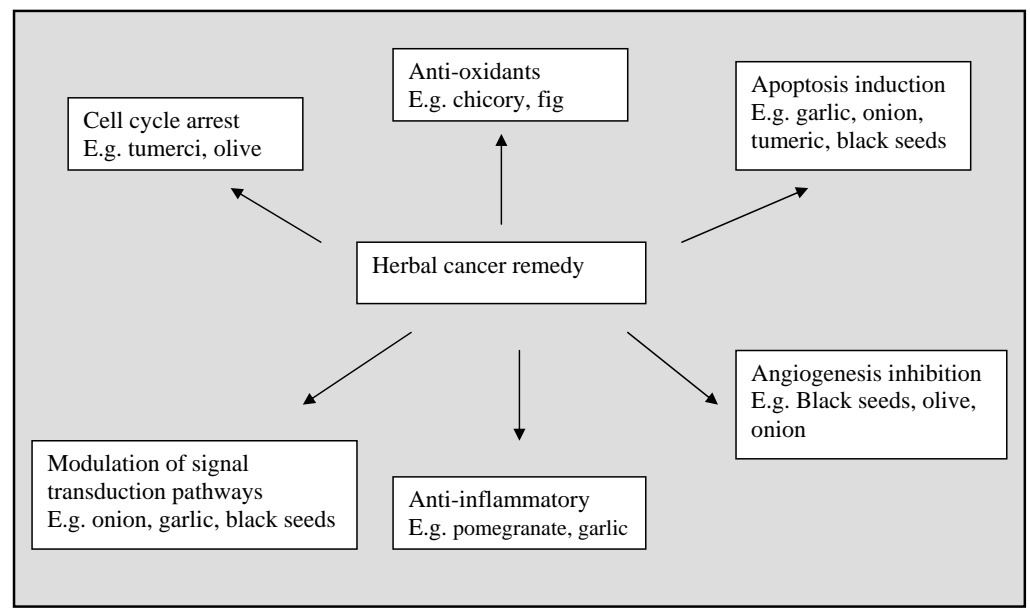

Fig. (3). Summary of the possible cellular targets of the herbal anti cancer derived drugs and extracts.

oil, Thymoquinone (TQ) is the main active compound [54]. TQ affects multiple targets, including suppression of, anti apoptotic genes expression (e.g, IAP1, IAP2, XIAP Bcl-2, Bcl-xL), NF-kappa B activation pathway and thus enhances apoptosis induction [55, 56]. Moreover, TQ inhibited cell proliferation of many types of cancer cell lines, including breast adenocarcinoma, ovarian adenocarcinoma [57], human pancreatic adenocarcinoma, colorectal cancer [58], uterine sarcoma [59], human osteosarcoma [60], neoplastic keratinocytes [61] and fibrosarcoma, lung carcinoma [55]. More recently, it was reported that TQ blocks tumor angiogenesis in vivo (mouse model) and in vitro (human umbilical vein endothelial cell -HUVEC). In HUVEC, TQ inhibited migration, invasion, proliferation, and tube formation by decreasing AKT/ERK activation [62].

\section{POMEGRANATE (PUNICA GRANATUM L.)}

The pomegranate has long been used in traditional Greco-Arab and Islamic medicine to treat a variety of ailments, including sort throat, inflammation and rheumatism. The fruit is also used for treating bladder disturbances, strengthening gums and soothing mouth ulcers. Pomegranates feature prominently in all religions, Judaism, Christianity, Islam, Buddhism and Zoroastrianism. According to the Qur'an, pomegranates grow in the gardens of paradise. Among the small number of fruits and vegetables mentioned in the Quran, (including date, olive, grape, banana, Fig, cucumber, garlic, lentil and onion) pomegranate is mentioned three times, indicating its significance in Muslims life.

The pomegranate (Punica granatum L.) fruit has been used for centuries in ancient cultures for medicinal purposes. For a long time, the fruit has been widely consumed fresh and, more recently, in beverage form as juice. Pomegranate is known as an anti- oxidant and is used to treat several diseases including cancer, inflammation, cardiovascular disease, diabetes, bacterial infections and antibiotic resistance, and ultraviolet radiation-induced skin damage [63, 64]. However, most of the research groups has focused on its antioxidant, anti-inflammatory and anticarcinogenic properties.

It is now well documented that pomegranate is effective in treating prostate cancer. In in-vitro experiments, Pomegranate fruit extract decrease proliferation and induced apop- tosis of DU-145 prostate cancer cells and suppressed invasive potential of PC-3 cells. These effects may be associated with plant based anti-inflammatory effects [65-67]. Moreover, Mukhtar and his colleges reported that oral administration of Pomegranate fruit extract resulted in significant inhibition of tumor growth in prostate tumor model mice [67]. Pomegranate fruit extract was also effective in inhibition of lung tumorigenesis in mice [68], suggesting that consuming pomegranates could potentially help reduce the growth and spread of prostate and lung cancer cells or even prevent cancer from developing. Pomegranate juice was also effective in inhibition of inflammatory cell signaling in colon cancer [69].

The pomegranate anticancer activities is not limited to its juice, but also the peel and seeds oil have been shown to be effective against tumor cell proliferation, cell cycle, invasion and angiogenesis [64]. Concomitant, pomegranate seed oil suppressed colon carcinogenesis in mice (induced by azoxymethane) [70]. For more details on the anti-carcinogenic effects of the different parts and compounds of the pomegranate, the reader is directed to excellent reviews [64, 71].

\section{OLIVE OIL AND LEAF (OLEA EUROPEA)}

Olive oil and olive leaf are cited in the Bible as a natural healer: "The fruit thereof shall be for meat and the leaf thereof for medicine". Prophet Muhammad (PBUH) said, "Eat olive oil and massage it over your bodies since it is a holy (Mubarak) tree". He also stated that olive oil cures 70 diseases. In the Arab-Islamic world, olive oil has been commonly used in cooking, cosmetics, pharmaceuticals, and soaps and as a fuel for traditional oil lamps.

\section{Anti-Cancer Properties}

Oxidative stress has been found to increase cancer occurrence and consumption of antioxidants (found in olive oil, fruits, and vegetables) is believed to reduce the risk of carcinogenesis. Anti cancer activity of olive oil is associated with its high content of antioxidants, e.g., hydroxytyrosol, tyrosol, secoiridoids and lignans. In addition the anticancer effects are attributed to olive-derived compounds deemed to be anticancer agents (such as squalene and terpenoids). 
In vitro investigations have found that olive oil phenols are potent antioxidants, which may provide potential chemoprotective properties. Hydroxytyrosol was found to induce apoptosis, to arrest cell cycle progression at the G1 phase, to protect cells from hydrogen peroxide-induced damage, and DNA from peroxynitrite-induced damage. In addition to antioxidant properties, oleuropein have been found to exhibit antiangiogenic effects and to inhibit cell growth, motility, and invasiveness. Furthermore, rapid tumor regression was observed when mice were given one-percent oleuropein in drinking water. Saturated animal fats and polyunsaturated plant fats in the diet have been implicated in colon, breast, prostate, and ovarian cancers. The substitution of olive oil in the Mediterranean diet may explain its apparent cancer chemopreventive effects.

When olive oil was compared to other oils, it was found that fried olive oil has a protective effect against colon cancer. Moreover, the incidence of breast cancer was $70 \%$ less in rats group fed olive oil than in the rats group fed safflower oil [72]. This agrees with data that unheated olive oil is beneficial in protecting against colon cancer. The heterocyclic amines (HCA) produced when protein-containing food is fried have been found to induce breast, colon, and pancreatic cancer in rats. When olive oil is used for frying, fewer HCAs are produced than when oils high in polyunsaturated fatty acids are used. Using specific cell lines, they investigated processes involved in cancer initiation, promotion, and metastasis-the three main stages in cancer development and concluded olive oil phenols exert beneficial effects in all three stages. The oil extract was shown to reduce DNA damage (initiation), increase barrier function (promotion), and reduce cell invasion of surrounding tissue (metastasis) [24, 73-75]. More recently, oleuropein and hydroxytyrosol, major phenolic compound of olive oil, decreased cell viability, inhibited cell proliferation, induced cell apoptosis in MCF-7 breast caner cells [76] and may possibly be used to prevent cardiotoxicity induced by doxorubicin [77]. In addition to the olive oil, the olive leaf is also effective in cancer prevention especially due to its phenolic compounds that exhibit powerful antioxidant activity [78]. phenolic extract obtained from virgin olive oil was effective as antiproliferative and apoptosis-inducer (Fig. 3) in HL60 cells [79].

\section{BREAD WHEAT (TRITICUM AESTIVUM L)}

Most of the studies that had investigated the roll of Triticum aestivum L (bread wheat) in cancer, e.g. colon cancer, where done indirectly as a cause effect study. For instance, several fiber food sources where tested in animals and in humans, and wheat bran has been one of the most effective in protecting against colon cancer [80]. Similarly, it was suggested that folic acid in wheat bread could prevent colon tumorigenesis [81]. Lignans (found in wheat) are also thought to be involved in cancer prevention by wheat bran in mice probably by apoptotic mechanisms [82]. In fact the protective effect of the bread wheat against colon tumurgenisis could be due to its high fiber content and cell wall byproducts that contain many bioactive components such as vitamins, lignans, isoflavones, and phenolic acids. These chemicals are able to act as antioxidants or by other mechanisms related to inhibition of tumor progression [83].

\section{DISCUSSION AND CONCLUDING REMARKS}

Despite the rapidly increasing understanding of the molecular and cellular processes, such as gene and protein expression, apoptosis, angiogenesis, signal transduction involved in carcinogenesis, the morbidity of this epidemiologic disease is still rising. Several drugs are used to treat and prevent the development of tumorgenesis. However, these treatments are not always effective and usually are accompanied with side effects. Alternative treatment, e.g., herbal plants might be a potential safe candidate for use and treatment of several diseases including cancer. Several studies have been conducted in vivo and in vitro to evaluate herbal plants efficacy on carcinogenesis treatment.

\section{The Wisdom of the Past Led to the Discovery of Chemo- preventive Drugs}

The past medical literature is a valuable source of information which has the potential suggestions to the contemporary scientists. Several studies have revealed that natural products exhibit an extensive spectrum of biological activities such as, stimulation of the immune system, antibacterial, antiviral, anti-hepatotoxic, anti-ulcer, anti-inflammatory, antioxidant, anti-mutagenic, and anti-cancer effects $[6,36$, $66,84-86]$. A variety of grains, cereals, nuts, soy products, olives, beverages such as tea and coffee, and spices including turmeric, garlic, ginger, black pepper, cumin and caraway confer a protective effect against cancer $[33,35,36,66$, $85,87]$. Several studies have also documented the relationship between decreased cancer risk and high consumption of vegetables, including cabbage, cauliflower, broccoli, brussels sprout, tomatoes, and fruits such as, apples and grapes $[6,33,86,88]$. In addition, a number of medicinal plants and herbs have also been reported to reduce the risk of cancer in multiple sites $[89,90]$.

Traditional herbal medicines provide a remarkable source for new drug development. Indeed, about $50 \%$ of the modern drugs are herbal based [91]. In the case of anti cancer drugs, various drugs are derived from plant sources including but not limited to paclitaxel (taxol), vinblastine, capsaicin, vincristine, the camptothecin derivatives, topotecan, irinotecan and etoposide [86, 92-94]. Many commonly used anti-cancer herbs possess chemopreventive effects within there diverse pharmacological properties. Since cancer evolves over a long period of time, agents that inhibit or retard one or more of its stages could affect the overall course of the disease. Certain micronutrients (like Oleuropein and Diallyl sulfide compounds found in olives and garlic respectively) possess potent cancer-preventive abilities.

\section{The Safety of Herbal Treatment}

The safety and effectiveness of alternative medicine is not always scientifically proven [95]. It is known that number of herbs are likely to cause adverse effects [5, 96, 97]. Unfortunately, many consumers believe that herbal medicines are safe because they are "natural". However, some of the plants extracts are poisonous or even lethal [6, 98]. It is tremendously vital to analysis the plant extract dosage toxicity before its usage. Herbal medicines may also interact with each other or synthetic drugs, causing toxicity to the patient. Therefore it is essential to determine the safety 
and efficacy of each plant before they can be recommended for medical use.

Some anti cancer herbal plants have been tested in vivo and in vitro as was discussed. However, some other herbals used traditionally to treat cancer (or other diseases), were not validated in a scientific laboratories. Care is needed when extrapolating in vitro data to in vivo models because it cannot be assumed that the effects seen when cells are exposed directly to active compounds that would be candidate chemopreventive agents, will be seen when they are consumed in the diet. We should investigate whether they are capable of distribution throughout the body when they are absorbed after ingestion. There is no doubt that it is the scientists (and perhaps the Physicians) mission to study the efficacy and biochemical action and cellular target of those plants extracts and active ingredients.

\section{ACKNOWLEDGEMENTS}

The authors would like to acknowledge USDAAgricultural Research Service (ARS) for providing their financial support.

\section{REFERENCES}

[1] Toni I, Flamini E, Mercatali L, Sacanna E, Serra P, Amadori D. Pathogenesis of osteoblastic bone metastases from prostate cancer. Cancer 2010; 116(6):1406-18

[2] Baguley BC. Multidrug resistance in cancer. Methods Mol Biol 2010; 596: 1-14.

[3] Yan Q, Wajapeyee N. Exploiting cellular senescence to treat cancer and circumvent drug resistance. Cancer Biol Ther 2010; 9(3): 16675.

[4] Saad B, Azaizeh H, Said O. Tradition and perspectives of arab herbal medicine: a review. Evid Based Complement Alternat Med 2005; 2(4): 475-9.

[5] Saad B, Azaizeh H, Abu-Hijleh G, Said O. Safety of traditional arab herbal medicine. Evid Based Complement Alternat Med 2006; 3(4): 433-9.

[6] Saad B, Azaizeh H, Said O. Arab herbal medicine. Bot Med Clin Pract 2008; 4: 31 .

[7] Shams AA, Altadawy Fi, Alashaab KH. Healing with Herbs in the past and present. Dar AlKutum Alelmeah, Beirut, Lebanon (in Arabic) 1991.

[8] Omar SH. Olive: Native of Mediterranean region and Health benefits. Pharmacognosy Rev 2008; 2(3): 135-42.

[9] Said O, Fulder S, Khalil K, Azaizeh H, Kassis E, Saad B. Maintaining a physiological blood glucose level with 'glucolevel', a combination of four anti-diabetes plants used in the traditional arab herbal medicine. Evid Based Complement Alternat Med 2008; 5(4): 4218.

[10] Avi Senna AH. AlKanoon Fi Altib (The Rules of Medicine). Four Volumes, 1993 by Iz Aldin Publications, Beirut, Lebanon (in Arabic) 1993 , p. 1037.

[11] Oumeish OY. The philosophical, cultural, and historical aspects of complementary, alternative, unconventional, and integrative medicine in the Old World. Arch Dermatol 1998; 134(11): 137386.

[12] Esposito JL. The Oxford History of Islam. Oxford-University Press 2000.

[13] Hitti PK. History of the Arab. Mac Millan St. Martin's Press 1970.

[14] Said O, Zaid H, Saad B. Greco-Arab and Islamic herbal medicine and cancer treatment/prevention. Foods, Herbs, and their Extracts: Cancer Treatment and Prevention, Ed. Watson and Preedy, Taylo\&Francis Group 2010: In press.

[15] Volanis D, Kadiyska T, Galanis A, Delakas D, Logotheti S, Zoumpourlis V. Environmental factors and genetic susceptibility promote urinary bladder cancer. Toxicol Lett 2010; 193(2):131-7.

[16] Chandra SA, Nolan MW, Marlarkey DE. Chemical Carcinogenesis of the Gastrointestinal Tract in Rodents: An Overview with Emphasis on NTP Carcinogenesis Bioassays. Toxicol Pathol 2010; 38(1):188-97.
[17] Brown KA, Simpson ER. Obesity and breast cancer: progress to understanding the relationship. Cancer Res 2010; 70(1): 4-7.

[18] Fuemmeler BF, Pendzich MK, Tercyak KP. Weight, Dietary Behavior, and Physical Activity in Childhood and Adolescence: Implications for Adult Cancer Risk. Obes Facts 2009; 2(3): 17986.

[19] Rhazes. AlHawy (The comprehensive). Dar AlKalam Publishing Beirut, Lebanon (in Arabic) 925.

[20] AlTurkimany JOA. AlMoatamad Fi Aladweah Almofradah, The source of the single pharmaceuticals. Revised by AlSaka, M. Dar AlKalam Publishing, Beirut, Lebanon (in Arabic). 1993.

[21] Munke L. AlTadawy Be Alashab Fi Masr Alkademeh (Healing with Herbs in Old Egypt). Maktabat Madbouly, Cairo, Egypt (in Arabic) 1993.

[22] Ibn AlBitar DAM. AlJame Li-Mofradat al Adwiyah wal Aghthiyah (The collection of Medical and Food Items). Two Volumes. Dar Sader Publishing, Beirut, Lebanon (in Arabic) 1874.

[23] Milner JA. Garlic: its anticarcinogenic and antitumorigenic properties. Nutr Rev 1996; 54(11 Pt 2): S82-6.

[24] Pasteur L. Memoire sur la fermentation appelle lactique. Ann Chim Phys Ser (in French) 1858; 52: 404.

[25] Mei X, Wang MC, Xu HX, et al. Garlic and gastric cancer-the effect of garlic on nitrite and nitrate in gastric juice. Acta Nutr Sin 1982; 4: 53-6.

[26] Takezaki T, Gao CM, Ding JH, Liu TK, Li MS, Tajima K. Comparative study of lifestyles of residents in high and low risk areas for gastric cancer in Jiangsu Province, China; with special reference to allium vegetables. J Epidemiol 1999; 9(5): 297-305.

[27] Dorant E, van den Brandt PA, Goldbohm RA, Sturmans F. Consumption of onions and a reduced risk of stomach carcinoma. Gastroenterology 1996; 110(1): 12-20.

[28] Steinmetz KA, Kushi LH, Bostick RM, Folsom AR, Potter JD. Vegetables, fruit, and colon cancer in the Iowa Women's Health Study. Am J Epidemiol 1994; 139(1): 1-15.

[29] Gao CM, Takezaki T, Ding JH, Li MS, Tajima K. Protective effect of allium vegetables against both esophageal and stomach cancer: a simultaneous case-referent study of a high-epidemic area in Jiangsu Province, China. Jpn J Cancer Res 1999; 90(6): 614-21.

[30] Setiawan VW, Yu GP, Lu QY, et al. Allium vegetables and stomach cancer risk in China. Asian Pac J Cancer Prev 2005; 6(3): 38795.

[31] Colli JL, Amling CL. Chemoprevention of prostate cancer: what can be recommended to patients? Curr Urol Rep 2009; 10(3): 16571 .

[32] Hsing AW, Chokkalingam AP, Gao YT, et al. Allium vegetables and risk of prostate cancer: a population-based study. J Natl Cancer Inst 2002; 94(21): 1648-51.

[33] Chan JM, Wang F, Holly EA. Vegetable and fruit intake and pancreatic cancer in a population-based case-control study in the San Francisco bay area. Cancer Epidemiol Biomarkers Prev 2005; 14(9): 2093-7.

[34] Kim JY, Kwon O. Garlic intake and cancer risk: an analysis using the Food and Drug Administration's evidence-based review system for the scientific evaluation of health claims. Am J Clin Nutr 2009; 89(1): 257-64.

[35] Challier B, Perarnau JM, Viel JF. Garlic, onion and cereal fibre as protective factors for breast cancer: a French case-control study. Eur J Epidemiol 1998; 14(8): 737-47.

[36] Boon H, Wong J. Botanical medicine and cancer: a review of the safety and efficacy. Expert Opin Pharmacother 2004; 5(12): 2485501.

[37] Sparnins VL, Barany G, Wattenberg LW. Effects of organosulfur compounds from garlic and onions on benzo[a]pyrene-induced neoplasia and glutathione S-transferase activity in the mouse. Carcinogenesis 1988; 9(1): 131-4.

[38] Sundaram SG, Milner JA. Diallyl disulfide induces apoptosis of human colon tumor cells. Carcinogenesis 1996; 17(4): 669-73.

[39] Sakamoto K, Lawson LD, Milner JA. Allyl sulfides from garlic suppress the in vitro proliferation of human A549 lung tumor cells. Nutr Cancer 1997; 29(2): 152-6.

[40] Welch C, Wuarin L, Sidell N. Antiproliferative effect of the garlic compound S-allyl cysteine on human neuroblastoma cells in vitro. Cancer Lett 1992; 63(3): 211-9.

[41] Takeyama H, Hoon DS, Saxton RE, Morton DL, Irie RF. Growth inhibition and modulation of cell markers of melanoma by S-allyl cysteine. Oncology 1993; 50(1): 63-9. 
[42] Zhang ZM, Yang XY, Deng SH, Xu W, Gao HQ. Anti-tumor effects of polybutylcyanoacrylate nanoparticles of diallyl trisulfide on orthotopic transplantation tumor model of hepatocellular carcinoma in BALB/c nude mice. Chin Med J (Engl) 2007; 120(15): 1336-42.

[43] Arnault I, Auger J. Seleno-compounds in garlic and onion. J Chromatogr A 2006; 1112(1-2): 23-30.

[44] Shenoy NR, Choughuley AS. Inhibitory effect of diet related sulphydryl compounds on the formation of carcinogenic nitrosamines. Cancer Lett 1992; 65(3): 227-32.

[45] Milner JA. Mechanisms by which garlic and allyl sulfur compounds suppress carcinogen bioactivation. Garlic and carcinogenesis. Adv Exp Med Biol 2001; 492: 69-81.

[46] Powolny AA, Singh SV. Multitargeted prevention and therapy of cancer by diallyl trisulfide and related Allium vegetable-derived organosulfur compounds. Cancer Lett 2008; 269(2): 305-14.

[47] L'Vova GN, Zasukhina GD. Modification of repair DNA synthesis in mutagen-treated human fibroblasts during adaptive response and the antimutagenic effect of garlic extract. Genetika 2002; 38(3): 306-9.

[48] Ban JO, Hwang IG, Kim TM, et al. Anti-proliferate and proapoptotic effects of 2,3-dihydro-3,5-dihydroxy-6-methyl-4Hpyranone through inactivation of NF-kappaB in human colon cancer cells. Arch Pharm Res 2007; 30(11): 1455-63.

[49] Malki A, El-Saadani M, Sultan AS. Garlic constituent diallyl trisulfide induced apoptosis in MCF7 human breast cancer cells. Cancer Biol Ther 2009; 8(22): 2175-85

[50] Gonzalez CA, Riboli E. Diet and cancer prevention: where we are, where we are going. Nutr Cancer 2006; 56(2): 225-31.

[51] Bianchini F, Vainio H. Allium vegetables and organosulfur compounds: do they help prevent cancer? Environ Health Perspect 2001; 109(9): 893-902.

[52] Zohary D, Hopf M. Domestication of plants in the old world: the origin and spread of cultivated plants in west asia, europe, and the nile valley. $3^{\text {rd }}$ ed. Oxford University Press 2007; 206.

[53] Musa D, Dilsiz N, Ulakoglu G, Ulakoglu G, Bitiren M. Antitumor activity of an ethanol extract of Nigella sativa seeds. Biologia 2004; 59: 735-40

[54] Ghosheh OA, Houdi AA, Crooks PA. High performance liquid chromatographic analysis of the pharmacologically active quinones and related compounds in the oil of the black seed (Nigella sativa L.). J Pharm Biomed Anal 1999; 19(5): 757-62.

[55] Kaseb AO, Chinnakannu K, Chen D, et al. Androgen receptor and E2F-1 targeted thymoquinone therapy for hormone-refractory prostate cancer. Cancer Res 2007; 67(16): 7782-8.

[56] Sethi G, Ahn KS, Aggarwal BB. Targeting nuclear factor-kappa B activation pathway by thymoquinone: role in suppression of antiapoptotic gene products and enhancement of apoptosis. Mol Cancer Res 2008; 6(6): 1059-70.

[57] Shoieb AM, Elgayyar M, Dudrick PS, Bell JL, Tithof PK. In vitro inhibition of growth and induction of apoptosis in cancer cell lines by thymoquinone. Int J Oncol 2003; 22(1): 107-13.

[58] Gali-Muhtasib H, Diab-Assaf M, Boltze C, et al. Thymoquinone extracted from black seed triggers apoptotic cell death in human colorectal cancer cells via a p53-dependent mechanism. Int J Oncol 2004; 25(4): 857-66.

[59] Worthen DR, Ghosheh OA, Crooks PA. The in vitro anti-tumor activity of some crude and purified components of blackseed, Nigella sativa L. Anticancer Res 1998; 18(3A): 1527-32.

[60] Roepke M, Diestel A, Bajbouj K, et al. Lack of p53 augments thymoquinone-induced apoptosis and caspase activation in human osteosarcoma cells. Cancer Biol Ther 2007; 6(2): 160-9.

[61] Gali-Muhtasib HU, Abou Kheir WG, Kheir LA, Darwiche N, Crooks PA. Molecular pathway for thymoquinone-induced cellcycle arrest and apoptosis in neoplastic keratinocytes. Anticancer Drugs 2004; 15(4): 389-99.

[62] Yi T, Cho SG, Yi Z, et al. Thymoquinone inhibits tumor angiogenesis and tumor growth through suppressing AKT and extracellular signal-regulated kinase signaling pathways. Mol Cancer Ther 2008; 7(7): 1789-96

[63] Jurenka JS. Therapeutic applications of pomegranate (Punica granatum L.): a review. Altern Med Rev 2008; 13(2): 128-44.

[64] Lansky EP, Newman RA. Punica granatum (pomegranate) and its potential for prevention and treatment of inflammation and cancer. J Ethnopharmacol 2007; 109(2): 177-206.

[65] Lansky EP, Jiang W, Mo H, et al. Possible synergistic prostate cancer suppression by anatomically discrete pomegranate fractions. Invest New Drugs 2005; 23(1): 11-20.
[66] Albrecht M, Jiang W, Kumi-Diaka J, et al. Pomegranate extracts potently suppress proliferation, xenograft growth, and invasion of human prostate cancer cells. J Med Food 2004; 7(3): 274-83.

[67] Malik A, Mukhtar H. Prostate cancer prevention through pomegranate fruit. Cell Cycle 2006; 5(4): 371-3.

[68] Khan N, Afaq F, Kweon MH, Kim K, Mukhtar H. Oral consumption of pomegranate fruit extract inhibits growth and progression of primary lung tumors in mice. Cancer Res 2007; 67(7): 3475-82.

[69] Adams LS, Seeram NP, Aggarwal BB, Takada Y, Sand D, Heber D. Pomegranate juice, total pomegranate ellagitannins, and punicalagin suppress inflammatory cell signaling in colon cancer cells. J Agric Food Chem 2006; 54(3): 980-5.

[70] Kohno H, Suzuki R, Yasui Y, Hosokawa M, Miyashita K, Tanaka T. Pomegranate seed oil rich in conjugated linolenic acid suppresses chemically induced colon carcinogenesis in rats. Cancer Sci 2004; 95(6): 481-6.

[71] Syed DN, Afaq F, Mukhtar H. Pomegranate derived products for cancer chemoprevention. Semin Cancer Biol 2007; 17(5): 377 85 .

[72] Owen RW, Giacosa A, Hull WE, Haubner R, Spiegelhalder B, Bartsch $\mathrm{H}$. The antioxidant/anticancer potential of phenolic compounds isolated from olive oil. Eur J Cancer 2000; 36(10): 1235 47.

[73] Covas MI. Bioactive effects of olive oil phenolic compounds in humans: reduction of heart disease factors and oxidative damage. Inflammopharmacology 2008; 16(5): 216-8

[74] Fito M, de la Torre R, Farre-Albaladejo M, Khymenetz O, Marrugat J, Covas MI. Bioavailability and antioxidant effects of olive oil phenolic compounds in humans: a review. Ann Ist Super Sanita 2007; 43(4): 375-81.

[75] Goulas V, Exarchou V, Troganis AN, et al. Phytochemicals in olive-leaf extracts and their antiproliferative activity against cancer and endothelial cells. Mol Nutr Food Res 2009; 53(5): 600-8.

[76] Han J, Talorete TP, Yamada P, Isoda H. Anti-proliferative and apoptotic effects of oleuropein and hydroxytyrosol on human breast cancer MCF-7 cells. Cytotechnology 2009; 59(1): 45-53.

[77] Andreadou I, Sigala F, Iliodromitis EK, et al. Acute doxorubicin cardiotoxicity is successfully treated with the phytochemical oleuropein through suppression of oxidative and nitrosative stress. J Mol Cell Cardiol 2007; 42(3): 549-58

[78] Visioli F, Galli C. Phenolics from olive oil and its waste products. Biological activities in in vitro and in vivo studies. World Rev Nutr Diet 2001; 88: 233-7.

[79] Fabiani R, De Bartolomeo A, Rosignoli P, et al. Virgin olive oil phenols inhibit proliferation of human promyelocytic leukemia cells (HL60) by inducing apoptosis and differentiation. J Nutr 2006; 136(3): 614-9

[80] Kritchevsky D. Protective role of wheat bran fiber: preclinical data Am J Med 1999; 106(1A): 28S-31S

[81] Omar RM, Ismail HM, El-Lateef BM, Youssif MI, Gomaa NF, Sheta M. Effect of processing on folic acid fortified Baladi bread and its possible effect on the prevention of colon cancer. Food Chem Toxicol 2009; 47(7): 1626-35.

[82] Qu H, Madl RL, Takemoto DJ, Baybutt RC, Wang W. Lignans are involved in the antitumor activity of wheat bran in colon cancer SW480 cells. J Nutr 2005; 135(3): 598-602.

[83] Johnson IT, Williamson G, Musk SR. Anticarcinogenic factors in plant foods: a new class of nutrients? Nutr Res Rev 1994; 7(1): 175-204.

[84] Saad B, Abouatta BS, Basha W, et al. Hypericum triquetrifoliumderived factors downregulate the production levels of LPS-induced nitric oxide and tumor necrosis factor-\{alpha\} in THP-1 cells. Evid Based Complement Alternat Med 2008. [Epub ahead of print].

[85] Al-Johar D, Shinwari N, Arif J, et al. Role of Nigella sativa and a number of its antioxidant constituents towards azoxymethaneinduced genotoxic effects and colon cancer in rats. Phytother Res 2008; 22(10): 1311-23

[86] Cragg GM, Newman DJ. Plants as a source of anti-cancer agents. J Ethnopharmacol 2005; 100(1-2): 72-9.

[87] Clifford JL, Digiovanni J. The promise of natural products for blocking early events in skin carcinogenesis. Cancer Prev Res (Phila Pa) 2010; 3(2):132-5.

[88] Vainio H, Weiderpass E. Fruit and vegetables in cancer prevention Nutr Cancer 2006; 54(1): 111-42.

[89] Park EJ, Pezzuto JM. Botanicals in cancer chemoprevention. Cancer Metastasis Rev 2002; 21(3-4): 231-55 
[90] Kroll DJ, Shaw HS, Oberlies NH. Milk thistle nomenclature: why it matters in cancer research and pharmacokinetic studies. Integr Cancer Ther 2007; 6(2): 110-9.

[91] Harvey AL. Natural products in drug discovery. Drug Discov Today 2008; 13(19-20): 894-901.

[92] Butler MS, Newman DJ. Mother Nature's gifts to diseases of man: the impact of natural products on anti-infective, anticholestemics and anticancer drug discovery. Prog Drug Res 2008; 65(1): 344.

[93] Cragg GM, Grothaus PG, Newman DJ. Impact of natural products on developing new anti-cancer agents. Chem Rev 2009; 109(7): 3012-43.
[94] Saklani A, Kutty SK. Plant-derived compounds in clinical trials. Drug Discov Today 2008; 13(3-4): 161-71.

[95] Talalay P. The importance of using scientific principles in the development of medicinal agents from plants. Acad Med 2001; 76(3): 238-47.

[96] Chandrasekaran CV, Sundarajan K, David K, Agarwal A. In vitro efficacy and safety of poly-herbal formulations. Toxicol In Vitro 2009; 24(3):885-97.

[97] Simaan JA. Herbal medicine, what physicians need to know. J Med Liban 2009; 57(4): 215-7.

[98] Elvin-Lewis M. should we be concerned about herbal remedies. J Ethnopharmacol 2001; 75(2-3): 141-64. 